\title{
STRATEGI IMPLEMENTASI PENDIDIKAN BERBASIS BUDAYA DINAS PENDIDIKAN DASAR KABUPATEN BANTUL
}

\author{
Khafidhatul Khasanah, Wiwik Wijayanti \\ Program Studi Manajemen Pendidikan PPs UNY, Universitas Negeri Yogyakarta \\ avied90@gmail.com, wiwikashari@gmail.com
}

\begin{abstract}
Abstrak
Penelitian ini bertujuan untuk mengetahui konsep dan strategi implementasi pendidikan berbasis budaya Dinas Pendidikan Dasar Kabupaten Bantul, dengan pendekatan kualitatif dan jenis fenomenologi. Data penelitian ini dikumpulkan dengan teknik wawancara mendalam dan studi dokumentasi. Teknik analisis data yang digunakan adalah teknik analisis interaktif dari Miles \& Huberman, yang meliputi reduksi data, penyajian data, penarikan kesimpulan dan verifikasi. Hasil penelitian adalah, pertama: Konsep pendidikan berbasis budaya adalah seluruh pengelolaan dan penyelenggaraan pendidikan yang dilaksanakan berdasarkan sistem pendidikan nasional dengan menjunjung tinggi nilai-nilai luhur budaya dan menjadikan kearifan lokal sebagai raw input, media, sekaligus orientasi pendidikan dalam rangka menggali nilai-nilai luhur budaya yang telah hidup dan tumbuh secara turun temurun untuk diaktualisasikan kembali dalam pendidikan. Kedua: Strategi implementasi pendidikan berbasis budaya Dinas Pendidikan Dasar Kabupaten Bantul terdiri atas: (a) merumuskan rencana program, (b) melibatkan stakeholders dalam proses penyusunan rencana implementasi, (c) menetapkan rencana strategis dan operasional, (d) menyusun strategi implementasi untuk Tingkat Satuan Pendidikan, (e) melakukan sosialisasi, (f) meningkatkan kapasitas sumber daya manusia, dan $(g)$ mempersiapkan sarana prasarana untuk menunjang implementasi pendidikan berbasis budaya.
\end{abstract}

Kata kunci: strategi implementasi, pendidikan berbasis budaya

\section{IMPLEMENTATION STRATEGY OF CULTURE-BASED EDUCATION IN BANTUL DISTRICT PRIMARY EDUCATION OFFICE}

\author{
Khafidhatul Khasanah, Wiwik Wijayanti \\ Program Studi Manajemen Pendidikan PPs UNY, Universitas Negeri Yogyakarta \\ avied90@gmail.com, wiwikashari@gmail.com
}

\begin{abstract}
This study aims to determine the concept and implementation strategy based education culture Bantul District Department of Basic Education, with a qualitative approach and type of phenomenology. The research data was collected by using in-depth interviews and documentation study. Data analysis technique used is the technique of interactive analysis of Miles $\mathcal{E}$ Huberman, which includes data reduction, data display, conclusion drawing and verification. This study shows two findings. First: The concept of education-based culture is the whole management and delivery of education implemented by the national education system to uphold the noble values of culture and make local wisdom as raw input, media, as well as the orientation of education in order to explore the noble values of the culture that has lived and grown for generations to be rebuild in education. Second: implementation strategy based education culture Basic Education Department Bantul consists of: (a) formulate plans based education programs of culture, $(b)$ involve stakeholders in the process of drafting an implementation plan based education culture, (c) establish strategic and operational plans, (d) strategize the implementation of culture-based education for the Education Unit, $(e)$ to disseminate culture-based education, $(f)$ increasing the capacity of human resources, and $(g)$ prepare the infrastructure to support the implementation of culture-based education.
\end{abstract}

Keywords: implementation strategy, culture-based education. 


\section{Pendahuluan}

Globalisasi memiliki implikasi positif pada kemajuan dan kecanggihan teknologi informasi, pertumbuhan ekonomi serta perubahan sosial budaya yang cukup pesat. Namun di sisi lain, globalisasi memberikan peluang yang seluas-luasnya bagi budaya negara-negara barat yang cenderung mengedepankan rasionalitas, mempengaruhi negara-negara timur termasuk Indonesia yang masih memegang adat dan budaya leluhur yang menjunjung tinggi nilai-nilai tradisi dan spiritualitas keagamaan. Kenyataan tersebut merupakan tantangan terbesar bagi bangsa Indonesia khususnya dunia pendidikan saat ini. Dalam kondisi inilah pendidikan terutama yang berorientasi menanamkan nilai-nilai budaya, memiliki landasan argumentatif yang cukup kuat untuk diimplementasikan.

Proses pendidikan merupakan upaya mewariskan nilai-nilai luhur suatu bangsa yang bertujuan melahirkan generasi unggul secara intelektual dengan tetap memelihara kepribadian dan identitas sebagai bangsa yang memiliki keluhuran budaya. Berdasarkan idealitas pendidikan tersebut, maka esensi pendidikan memiliki dua misi utama yaitu "transfer of values" dan juga "transfer of knowledge".

Kebudayaan tidak dapat dipisahkan dari pendidikan, bahkan kebudayaan merupakan alas atau dasar pendidikan. Rumusan ini menjangkau jauh ke depan, sebab dikatakan bukan hanya pendidikan itu dialaskan pada suatu aspek kebudayaan yaitu aspek intelektual, tetapi kebudayaan sebagai keseluruhan. Kebudayaan yang menjadi alas pendidikan tersebut haruslah bersifat kebangsaan. Dengan demikian kebudayaan yang dimaksud adalah kebudayaan yang riil yaitu budaya yang hidup dan berkembang di dalam masyarakat Indonesia.

Penetrasi kebudayaan asing terhadap kebudayaan bangsa Indonesia telah mereduksi nilai-nilai luhur budaya masyarakat. Realitas sosial masyarakat yang saat ini terjadi tentu harus menjadi perhatian serius bagi semua pihak. Persoalan-persoalan sosial masyarakat yang setiap hari diper- tontonkan dan dipublikasikan melalui media cetak dan elektronik menunjukkan betapa bobrok moralitas dan perilaku masyarakat. Mulai dari praktek korupsi yang dilakukan oleh para pejabat negara, tawuran yang dilakukan oleh pelajar, narkoba dan minuman keras yang semakin mudah diperoleh oleh semua kalangan, pergaulan dan seks bebas yang sudah tidak tabu, pola kehidupan konsumtif dan hedonis yang semakin tidak terbendung, kepekaan dan solidaritas sosial yang semakin terkikis, kebudayaan lokal dianggap sesuatu yang kuno, karena kebudayaan barat dianggap lebih modern dan kekinian.

Dalam realitas kehidupan masyarakat saat ini, tidak sedikit yang mulai meninggalkan nilai-nilai budaya khususnya budaya Jawa dalam kehidupan sehari-hari. Dalam hal ini lembaga pendidikan adalah sebagai instrumen yang cukup strategis untuk menanamkan, melestarikan dan juga mengembangkan nilai-nilai luhur budaya yang ada di suatu daerah, namun belum ada perubahan radikal dalam aspek pendidikan di Daerah Istimewa Yogyakarta yang kaitannya dengan pendidikan berbasis budaya. Hal ini tentunya dikarenakan banyak dari lembaga pendidikan yang sulit untuk keluar dari kemapanan sistem yang telah lama dibangun dan dijalankan, sehingga sulit untuk menerima dan melaksanakan kebijakan yang baru.

Selain itu, pendidikan berbasis budaya cenderung dipahami sebatas kepada aspek formalitas pendidikan, seperti penambahan mata pelajaran bahasa Jawa dalam desain kurikulum lembaga pendidikan, atau penambahan kegiatan ekstra kurikuler yang berkaitan dengan pelestarian budaya lokal. Padahal seharusnya pendidikan berbasis kebudayaan sebagaimana telah disebutkan sebelumnya tidaklah cukup sebatas formalisasi kebudayaan dalam praktik pembelajaran, namun lebih kepada proses internalisasi nilai-nilai budaya luhur dalam setiap desain kurikulum dan praktik pembelajaran yang berlangsung. Untuk dapat menanamkan nilai-nilai luhur budaya melalui pendidikan membutuhkan pemahaman yang utuh mengenai konsep pendi- 
dikan berbasis budaya, namun pemahaman mengenai konsep pendidikan berbasis budaya itu sendiri belum optimal baik dari pihak Dinas pendidikan tingkat Kabupaten maupun pada tingkat satuan pendidikan di Kabupaten Bantul. Untuk mencapai tujuan dari pendidikan berbasis budaya secara utuh maka sangat penting adanya pemerataan implementasi pendidikan berbasis budaya di Kabupaten Bantul. Namun kondisi saat ini yang terjadi adalah implementasi pendidikan berbasis budaya masih pada Sekolah Dasar dan belum semua sekolah melaksanakan pendidikan berbasis budaya di Kabupaten Bantul.

Fokus penelitian ini adalah konsep pendidikan berbasis budaya dan strategi implementasi pendidikan berbasis budaya Dinas Pendidikan Dasar Kabupaten Bantul. Hasil penelitian ini diharapkan dapat memberikan sumbangan pemikiran dalam pengembangan ilmu manajemen pendidikan terutama pada konsep pendidikan berbasis budaya dan memberikan bahan kajian penelitian dan khazanah keilmuan tentang strategi implementasi pendidikan berbasis budaya. Selain itu, hasil penelitian ini dapat dijadikan sebagai bahan kajian bagi Pemerintah Daerah Istimewa Yogyakarta dan Pemerintah Kabupaten Bantul dalam melaksanakan pendidikan berbasis budaya, serta dijadikan sebagai bahan informasi bagi lembaga pendidikan dalam melaksanakan pendidikan berbasis budaya.

Pendidikan Berbasis Budaya

Basri (2013, p. 13) mengartikan "Pendidikan sebagai proses pembinaan dan pembimbingan yang dilakukan seseorang secara terus menerus kepada anak didik untuk mencapai tujuan pendidikan." Pendidikan adalah khas manusia artinya hanya manusia saja yang memiliki eksistensi kehidupan yang memiliki persoalan pendidikan. Manusia secara kodrati adalah makhluk pendidikan, potensi kodrati manusia yaitu cipta, rasa dan karsa memiliki kemampuan untuk dididik dan mendidik. Kemampuan dididik berarti ketiga potensi kejiwaan manusia sejak kecil bisa menerima perawatan dan bimbingan dari orang lain. Sedangkan kemampuan mendidik berarti pada tingkat kesadaran dan keberadaan tertentu, manusia bisa melakukan perawatan, pertolongan dan pembimbingan kepada orang lain.

Pendidikan merupakan suatu proses "akulturasi", hal ini ditunjukkan dengan proses modifikasi dari satu budaya melalui interaksi yang berkelanjutan dengan budaya yang lain. Sebagaimana yang dijelaskan oleh Pai (1990, p. 39) bahwa "Education as an acculturation process can also be viewed as the modification of one culture through continuous contact with another."

Dari berbagai penjelasan mengenai pendidikan tersebut dapat dipahami bahwa pendidikan merupakan sebuah sistem yang terencana untuk menciptakan suasana belajar dalam proses pembelajaran agar peserta didik dapat mengembangkan semua potensi yang ada dalam diri yang berorientasi pada nilai-nilai dan pelestarian serta pengembangan kebudayaan yang berhubungan dengan usaha-usaha pengembangan manusia. Pada dasarnya pendidikan merupakan suatu upaya untuk membuat manusia menjadi lebih baik, dalam arti kehidupan menjadi lebih berkembang. Dengan pendidikan, manusia akan berusaha untuk meningkatkan kehidupan yang lebih baik dari tingkat kehidupan naluriah menjadi nasional berkebudayaan. Oleh karena itu, bisa dikatakan bahwa pendidikan dapat diartikan sebagai pembudayaan kehidupan manusia.

Kata "kebudayaan" berasal dari bahasa Sanskerta yaitu buddhayah, yang merupakan bentuk jamak dari buddhi (budi atau akal). Kebudayaan dapat diartikan sebagai hal-hal yang berkaitan dengan budi dan akal manusia. Sedangkan apabila dilihat dari kata dasarnya yaitu "budaya" yang merupakan bentuk majemuk dari budi yang berarti akal. Jadi budaya artinya memiliki pikiran dan akal budi, sedangkan kebudayaan merupakan hasil dari kegiatan, pengetahuan dan penciptaan akal budi manusia.

Budaya merupakan sesuatu yang luas cakupannya, sebagaimana yang disebutkan oleh Kottak (1974, p. 37) "Culture includes much more than refinement, taste, 
sophistification, education, and appreciation of the fine arts." Taylor (1871, p. 1) juga menjelaskan bahwa "Culture is that complex whole which includes knowledge, belief, art, morals, law, custom, and any other capabilities and habits acquired by man as a member of society. The condition of culture among the various societies of mankind, in so far as it is capable of being investigated on general principles, is a subject apt for the study of laws of human thought and action." Pendapat Taylor tersebut menjelaskan bahwa budaya merupakan sesuatu yang kompleks, di dalamnya ada pengetahuan, kepercayaan, seni, moral, dan hukum serta kebiasaan lain manusia sebagai anggota masyarakat.

Berdasarkan pendapat tersebut, tampak jelas bahwa budaya bukanlah sesuatu yang sederhana, namun penuh dengan kompleksitas di dalamnya yaitu budaya itu sendiri, bagaimana proses budaya tersebut tercipta dan mendapatkan bentuknya, serta siapa yang menciptakan dan mengubahnya. Hal ini menunjukkan bahwa budaya tidak lahir begitu saja (given), namun ada proses, lingkungan dan aktor yang terlibat di dalamnya. Nieto (2010, p. 136) menegaskan bahwa "Culture do not exist in a vacuum, but rather are situated in particular historical, social, political, and economic conditions, and therefore they are influenced by issues of power."

Pengaruh sosial, ekonomi, dan politik dalam proses pembentukan dan perkembangan budaya tampak sangat dominan, hal ini karena sosial, ekonomi dan politik mampu menjadi medium hegemonik bahkan determinatif bagi yang menguasainya. Kekuasaan atas status sosial, ekonomi dan politik dapat dengan mudah dimanfaatkan untuk mempengaruhi serta membentuk pola kehidupan masyarakat. Sebagaimana dijelaskan oleh Nieto (2010, p. 141) bahwa "In essence, then, culture is deeply entangled with economic and political privilege. That is, the tastes, values, languages, and dialect that have the greatest status are associated with the dominant social class not because these tastes, values, languages, or dialect are inherently better because they have higher social prestige as determined by the group with the greatest power."
Berdasarkan penjelasan sebelumnya, dapat disimpulkan bahwa kebudayaan atau budaya merupakan sesuatu yang diciptakan (social construct) bukan hadir dengan sendirinya (given), sebagaimana disimpulkan oleh Nieto (2010, p. 143) bahwa "Culture can be thought of as a construction-it constructs us and we construct it. Culture, then, is not a passive legacy, but an active operation that take place through contact and interaction with others. Culture is a social construction because it cannot exist outside of social contact and collaboration."

Dalam perspektif lain, budaya juga dijadikan sebagai instrumen untuk melakukan hegemoni oleh satu kelompok kepada kelompok yang lain. Globalisasi tanpa disadari juga membawa misi tersebut, dimana globalisasi melakukan kampanye budaya yang mengarahkan dan mengonstruk pola pikir dan pola laku masyarakat sebagaimana yang diinginkan oleh yang memiliki kuasa (power), sehingga apa yang diinginkan oleh kelompok yang memiliki kuasa ditransformasikan melalui kampanye budaya agar menghegemoni pola pikir dan pola laku kehidupan masyarakat dunia sebagaimana yang mereka inginkan. Friedman (1994, p. 40) menjelaskan bahwa "We have considered the way in which cultural identity might be understood in relation to the dynamics of global relation and I have argued that there are inverse cultural cycles that accompany the cycles of global hegemony."

Pola kehidupan manusia senantiasa berubah dari waktu ke waktu, begitu pula kebudayaan. Budaya yang pada hakikatnya tidak terpisah dari manusia itu sendiri mengalami perubahan seiring dengan perkembangan dan kemajuan yang dialami oleh kehidupan manusia. Oleh karena itu, kebudayaan bukanlah suatu yang statis, stagnan dan steril dari nilai-nilai yang berkembang dimana budaya tersebut tumbuh. Seperti yang dikemukakan oleh Nieto (2010, p. 137) "Cultural change is not simply a one-way process. The popular conception of culture change is that it is much like a transfusion: As one is emptied out of person, a new one is poured in." 
Pengintegrasian kebudayaan lokal dalam kurikulum dan proses pembelajaran merupakan strategi yang paling efektif dalam mengimplementasikan pendidikan berbasis budaya, namun perlu adanya kerja sama semua pihak untuk mewujudkannya, baik dari pemerintah, tokoh masyarakat, tokoh budaya, lembaga pendidikan, pendidik, maupun orang tua peserta didik. Hal ini penting agar desain kurikulum dan pembelajaran tidak melenceng dari esensi kebudayaan lokal itu sendiri dan mampu bersinergi dengan pengetahuan di luar dari pengetahuan lokal. Sebagaimana yang disampaikan oleh Meliono (2011, p. 232) "In line with the practical side of the education, the curriculum implementation has to be culturebased using the Nusantara thought, local wisdom, and multiculturalism. With this idea, learners will have a national perspective based on the three areas of study set by the curriculum as direction and guide in the teaching and learning process."

Thut \& Adams (2005, p. 526) menjelaskan bahwa pendidikan dapat menjadi akselarator perkembangan masyarakat menuju kehidupan yang lebih baik, jika pendidikan dikelola oleh pemimpin yang tepat, namun pendidikan juga dapat membengkokkan nilai-nilai suatu masyarakat, pendidikan juga dapat digunakan sebagai media untuk mempertahankan status quo jika pendidikan dikelola dan dikendalikan oleh pemimpin yang salah. Bagi negara berkembang, banyak pemimpin yang menyadari untuk menempatkan pendidikan sebagai medium penting dan menentukan bagi proses pembangunan, karena sistem pendidikan mampu merekontruksi lingkungan sosial dan ekonomi, namun kesadaran itu sangat sedikit yang diimbangi dengan visi dan misi yang suci, melainkan kebanyakan memanfaatkan medium pendidikan sebagai sarana untuk melanggengkan kekuasaan.

Secara konseptual, pendidikan berbasis budaya adalah model penyelenggaraan pendidikan yang bertumpu pada prinsip "dari konsep budaya, digerakkan oleh budaya dan untuk menciptakan budaya baru yang bercorak dan bernilai lebih dari budaya sebelumnya". Pendidikan dengan konsep budaya artinya pendidikan memberikan jawaban dan solusi atas penciptaan budaya yang didasari oleh kebutuhan masyarakat, tentu dengan tata nilai dan sistem yang berlaku di dalamnya. Pendidikan berbudaya artinya masyarakat sebagai pemilik budaya dengan segala tatanan nilai dan sistemnya ditempatkan sebagai subjek/pelaku pendidikan, bukan objek pendidikan. Pada konteks ini, semua unsur yang melingkupi masyarakat dapat berperan aktif dalam terciptanya sebuah budaya yang melingkupi masyarakat itu sendiri.

Desain pendidikan berbasis budaya dalam lingkup yang lebih luas mengacu kepada pembebasan, penyadaran dan kreativitas. Praktik pendidikan yang mengusung kompetensi/kodrat alami anak didik, bukan dengan perintah paksaan, tetapi dengan tuntunan, sehingga menggugah perkembangan kehidupan anak didik baik lahir maupun batin. Cara pendidikan seperti ini dikenal dengan pendekatan among. Ada dua hal yang mendasari adanya pendekatan tersebut. Pertama, kemerdekaan sebagai syarat untuk menghidupkan dan menggerakkan kekuatan lahir maupun bathin, hingga dapat hidup merdeka. Kedua kodrat alam sebagai syarat untuk menghidupkan dan mencapai kemajuan dengan secepatcepatnya dan sebaik-baiknya.

Berdasarkan penjelasan tersebut, maka dapat diambil kesimpulan bahwa pendidikan berbasis budaya adalah sebuah proses pendidikan yang diselenggarakan berdasarkan nilai-nilai luhur budaya agar peserta didik dapat mengembangkan potensi diri sehingga menjadi manusia yang memiliki keunggulan, kecerdasan, kearifan, budi luhur, peka terhadap lingkungan dan sadar akan keragaman serta tanggap terhadap perkembangan dunia. Oleh karena itu, pendidikan merupakan upaya mentransformasikan nilai-nilai budaya agar mencapai kemajuan baik individual maupun masyarakat. Kedudukan dan fungsi pendidikan sebagai pusat pengembangan kebudayaan, pusat kajian, dan pengembangan ilmu pengetahuan untuk mencapai kemajuan peradaban manusia. 
Donal van Meter \& Carl van Horn (Wahab, 2015, pp. 164-166) mengemukakan bahwa terdapat enam variabel yang mempengaruhi kinerja implementasi kebijakan yakni; pertama, standar dan sasaran kebijakan, di mana standar dan sasaran kebijakan harus jelas dan terukur sehingga dapat direalisir, apabila standar dan sasaran kebijakan kabur maka akan sulit untuk direalisasikan. Kedua, sumberdaya, dimana implementasi kebijakan perlu dukungan sumberdaya, baik sumber daya manusia maupun sumber daya non manusia. Ketiga, hubungan antar organisasi, yaitu dalam banyak program, implementor sebuah program perlu dukungan dan koordinasi dengan instansi lain, sehingga diperlukan koordinasi dan kerja sama antar instansi bagi keberhasilan suatu program. Keempat, karakteristik agen pelaksana yaitu mencakup stuktur birokrasi, norma-norma dan pola-pola hubungan yang terjadi dalam birokrasi yang semuanya itu akan mempengaruhi implementasi suatu program. Kelima, kondisi sosial, politik, dan ekonomi. Variable ini mencakup sumberdaya ekonomi lingkungan yang dapat mendukung keberhasilan implementasi kebijakan, sejauh mana kelompok-kelompok kepentingan memberikan dukungan bagi implementasi kebijakan, karakteristik para partisipan, yakni mendukung atau menolak, bagaimana sifat opini publik yang ada di lingkungan, serta apakah elite politik mendukung implementasi kebijakan. Keenam, Disposisi implementor yang mencakup tiga hal yang penting, yaitu respon implementor terhadap kebijakan, yang akan mempengaruhi kemauannya untuk melaksanakan kebijakan, kognisi yaitu pemahaman terhadap kebijakan, intensitas disposisi implementor, yaitu preferensi nilai yang dimiliki oleh implementor.

Dari uraian tersebut dapat diketahui bahwa implementasi kebijakan terdiri atas tujuan atau sasaran kebijakan, aktivitas, atau kegiatan pencapaian tujuan, dari hasil kegiatan, sehingga dapat disimpulkan bahwa implementasi merupakan suatu proses yang dinamis, dimana pelaksana kebijakan melakukan suatu aktivitas atau kegiatan, sehingga pada akhirnya akan mendapatkan suatu hasil yang sesuai dengan tujuan atau sasaran kebijakan itu sendiri. Keberhasilan suatu implementasi kebijakan dapat diukur atau dilihat dari proses dan pencapaian tujuan hasil akhir (output), yaitu tercapai atau tidaknya tujuan-tujuan yang ingin diraih.

Apabila proses implementasi kebijakan telah berjalan, maka diharapkan akan muncul suatu keluaran yaitu hasil segera (effect) dan dampak akhir (impact). Hasil segera adalah pengaruh atau akibat jangka pendek yang dihasilkan oleh suatu implementasi kebijakan, sedangkan dampak kebijakan adalah sejumlah akibat yang dihasilkan oleh implementasi kebijakan melalui proses jangka panjang. Hasil segera dan dampak yang ditimbulkan akan sangat berguna untuk menilai implementasi dari suatu kebijakan.

Inti dari masalah dalam implementasi kebijakan adalah bagaimana kebijakan dibuat sesuai dengan ketersediaan sumber daya. Menyadari langkah yang diperlukan untuk pelaksanaan pengendalian dan evaluasi. Melaksanakan implementasi kebijakan tidak dapat dipisahkan dari faktorfaktor yang mendukung dan menghambat atas pelaksanaan kebijakan.

Pelaksanaan kebijakan yang efektif ditentukan oleh komunikasi, sumber daya, disposisi atau sikap dan struktur organisasi. Komunikasi berkaitan dengan bagaimana kebijakan dikomunikasikan kepada organisasi atau masyarakat, ketersediaan sumber daya untuk menerapkan kebijakan, sikap dan respon dari pihak yang terlibat dan bagaimana struktur organisasi pelaksana kebijakan. Sumber daya berkaitan dengan ketersediaan sumber daya itu sendiri, terutama sumber daya manusia.

Penerapan kebijakan publik tidak akan mudah karena banyak faktor yang mempengaruhi. Faktor-faktor ini adalah faktor komunikasi, disposisi sumber daya manusia dan struktur birokrasi. Ada hubungan yang saling mempengaruhi antara komunikasi dan struktur birokrasi, komunikasi dengan sumber daya manusia, sumber daya manusia dengan struktur birokrasi. 
Berdasarkan uraian tersebut, maka strategi implementasi adalah sebuah cara dan upaya untuk melaksanakan sesuatu yang telah direncanakan dalam rangka mencapai tujuan dari apa yang telah ditetapkan dengan mengoptimalkan segala sumber daya yang ada.

\section{Metode Penelitian}

Pendekatan yang digunakan dalam penelitian ini adalah pendekatan kualitatif dengan jenis fenomenologi. Tempat penelitian ini adalah Dinas Pendidikan Dasar Kabupaten Bantul, SD Sendangsari Pajangan Kabupaten Bantul, SD 1 Trirenggo Klembon Kabupaten Bantul dan SD 1 Petir Piyungan Kabupaten Bantul. Adapun waktu penelitian yang dilaksanakan mulai dari bulan Januari 2015 sampai bulan April 2015 dan melakukan penelitian tambahan pada bulan Januari 2016.

Dalam penelitian ini, peneliti menggunakan unit analisis organisasi yang mencakup (1) Dinas Pendidikan Dasar Kabupaten Bantul, (2) SD Sendangsari Pajangan Kabupaten Bantul, (3) SD 1 Trirenggo Klembon Kabupaten Bantul dan (4) SD 1 Petir Piyungan Kabupaten Bantul.

Teknik yang dipilih dalam menentukan sumber data adalah purposive sampling. Subyek dalam penelitian ini adalah kepala Dinas Pendidikan Dasar Kabupaten Bantul, sekretaris, Kepala bidang bina program, kepala bidang Sekolah Dasar, Ketua Pokja PPD (Kelompok Kerja Pengembangan Pendidikan Dasar) Dinas Pendidikan Dasar Kabupaten Bantul, kepala sekolah dan guru SD Sendangsari Pajangan Kabupaten Bantul, kepala sekolah dan guru SD 1 Trirenggo Klembon Kabupaten Bantul dan kepala sekolah dan guru SD 1 Petir Piyungan Kabupaten Bantul.

Adapun teknik pengumpulan data yang digunakan dalam penelitian ini adalah wawancara dan analisis dokumen. Wawancara ang dilakukan dalam penelitian ini adalah wawancara secara mendalam (in-depth interview) dengan teknik wawancara semiterstruktur (semistructure interview). Instrumen yang digunakan dalam penelitian ini adalah peneliti itu sendiri, sedangkan Instrumen yang dikembangkan adalah pedoman wawancara mendalam (indepth interview).

Keabsahan data yang digunakan dalam penelitian ini adalah trianggulasi. Trianggulasi yang digunakan adalah trianggulasi sumber dan trianggulasi teknik. Trianggulasi sumber dilakukan untuk menguji kredibilitas data dilakukan dengan cara mengecek data yang telah diperoleh melalui beberapa sumber. Trianggulasi sumber yang penulis lakukan adalah dengan cross check antarresponden. Sedangkan trianggulasi teknik untuk menguji kredibilitas data yang dilakukan dengan cara mengecek data kepada sumber yang sama dengan teknik yang berbeda.

Teknik analisis data yang digunakan dalam penelitian ini adalah analisis data kualitatif. Miles \& Huberman (1994, pp. 1012) mengemukakan bahwa aktivitas dalam analisis data kualitatif dilakukan secara interaktif dan berlangsung secara terus menerus pada setiap tahapan penelitian sampai tuntas dan mencapai titik jenuh. Adapun tahap-tahap analisis data yang dilakukan adalah Data Reduction (Reduksi Data), Data Display (Penyajian Data), dan Conclusion Drawing and Verification (Penarikan Kesimpulan dan Verifikasi).

\section{Hasil Penelitian dan Pembahasan}

Situasi dan kondisi Kabupaten Bantul baik dari sisi kesejarahan, kondisi geografis dan kondisi dinamika penduduk, maupun kondisi sosial, agama, politik, budaya dan ekonomi menunjukkan bahwa kabupaten Bantul secara mayoritas merupakan daerah agraris. Daerah agraris mencirikan masyarakat yang teguh kepada tradisi dan kaya akan kearifan-kearifan yang secara alamiah tumbuh dan berkembang di tengah-tengah kehidupan masyarakat. Situasi dan kondisi ini secara langsung atau tidak langsung akan mendukung bagi terimplementasinya pendidikan berbasis budaya, karena keberadaan sekolah dalam melaksanakan pendidikan berbasis budaya akan didukung oleh keberadaan masyarakat yang masih memi- 
liki komitmen dan cinta terhadap budaya lokal.

Dinas Pendidikan Kabupaten Bantul merupakan organisasi Dinas dilingkungan Pemerintah Kabupaten Bantul yang dibentuk berdasarkan undang-undang Nomor 22 tahun 1999 tentang pemerintah Daerah dan PP Nomor 25 tahun 2000 tentang kewenangan pemerintah dan kewenangan propinsi sebagai daerah otonom, maka dasar hukum dinas pendidikan Kabupaten Bantul sesuai dengan Peraturan Daerah Kabupaten Bantul Nomor 16 Tahun 2007 Tentang Pembentukan Dan Organisasi Dinas daerah di lingkungan pemerintah Kabupaten Bantul. Kedudukan Dinas Pendidikan Dasar Kabupaten Bantul adalah sebagai unsur pelaksana Pemerintah Daerah khusus di bidang Pendidikan dasar. Sedangkan fungsi Dinas Pendidikan Dasar Kabupaten Bantul adalah sebagai pelaksana pemerintah daerah di bidang pendidikan dasar dan lingkup tugasnya adalah mengelolan manajemen Sekolah Dasar (SD) dan Sekolah Menengah Pertama (SMP).

Pendidikan berbasis budaya dalam Peraturan Daerah Istimewa Yogyakarta Nomor 5 Tahun 2011 Bab I Pasal 1 ayat (8) adalah pendidikan yang diselenggarakan untuk memenuhi standar nasional pendidikan yang diperkaya dengan keunggulan komparatif dan kompetitif berdasar nilainilai luhur budaya agar peserta didik secara aktif dapat mengembangkan potensi diri sehingga menjadi manusia yang unggul, cerdas, visioner, peka terhadap lingkungan dan keberagaman budaya, serta tanggap terhadap perkembangan dunia. Pengembangan pendidikan berbasis budaya adalah untuk melestarikan dan mengembangkan budaya Daerah Istimewa Yogyakarta yang mencakup nilai-nilai luhur, artefak dan adat istiadat dalam setiap aspek kehidupan bermasyarakat.

Pendidikan berbasis budaya sebagaimana yang tertuang dalam Peraturan Daerah Istimewa Yogyakarta Nomor 5 Tahun 2011 merupakan konsepsi yang dibangun untuk menempatkan budaya lokal yang tumbuh dan berkembang di Daerah Istimewa Yogyakarta sebagai bagian yang tidak terpisahkan dalam proses pendidikan dan perkembangan peserta didik. Hal ini sebagaimana yang diungkapkan oleh Tirtharahardja \& La Sulo (2005, p. 33) bahwa pendidikan sebagai proses transformasi budaya artinya sebagai kegiatan pewarisan budaya dari satu generasi ke generasi yang lain.

Berdasarkan temuan peneliti tentang pendidikan berbasis budaya di Dinas Pendidikan Dasar Kabupaten Bantul bahwa pendidikan berbasis budaya lahir disebabkan oleh beberapa faktor yaitu : Pertama, secara informal (hidden curriculum), budaya lokal telah terintegrasi dalam proses pendidikan di sekolah. Kedua, melalui pendidikan berbasis budaya maka dapat menciptakan generasi penerus bangsa yang memiliki kepribadian Indonesia dan tetap menjadikan budaya adi luhur sebagai hal yang diutamakan dalam pola pikir, pola laku dan pola sikapnya. Ketiga, globalisasi dengan berbagai produk kebudayaan yang dilahirkannya, telah menempatkan kebudayaan lokal dalam posisi sub-ordinatif.

Tuntutan perubahan pola kehidupan merupakan suatu keniscayaan, sehingga penolakan terhadap perubahan tuntutan zaman adalah hal yang mustahil untuk dilakukan. Namun yang perlu dilakukan adalah bagaimana kekuatan dan kemampuan masyarakat yang memegang teguh nilai-nilai luhur budaya harus dioptimalkan dalam menciptakan pola kehidupan sosial budaya di tengah-tengah masyarakat. Sebagaimana yang ditegaskan oleh Nieto (2010, p. 143) bahwa kebudayaan itu merupakan sesuatu yang diciptakan, bukan ada dengan sendirinya (given).

Berdasarkan temuan penelitian, adapun tujuan pendidikan berbasis budaya Dinas Pendidikan Dasar Kabupaten Bantul adalah sebagai berikut: Pertama, melestarikan nilai-nilai budaya jawa dan kearifan lokal yang ada di Bantul. Kedua, mengembangkan segala potensi yang ada di setiap wilayah di Bantul. Ketiga, menyiapkan manusia yang memiliki karakter atau berkepribadian Indonesia, cinta tanah air dan bangsa. Keempat, memiliki jiwa yang luhur, berbudaya, dapat menjadi teladan, rela 
berkorban, kreatif, inovatif dan professional. Kelima, Responsif terhadap perkembangan global dengan tidak meninggalkan nilai-nilai luhur budaya lokal Keenam, mewujudkan masyarakat yang berbudaya.

Landasan Pendidikan Berbasis Budaya

\section{Landasan Filosofis}

Landasan filosofis sebagaimana yang dijelaskan Tirtharahardja \& La Sulo (2005, pp. 83-84) bahwa landasan filosofis merupakan landasan yang bersifat filsafat, maka landasan filosofis dari pendidikan berbasis budaya di Dinas Kabupaten Bantul adalah sebagai berikut: Pertama, Pancasila dan Kepribadian Indonesia. Kedua, Falsafah Jawa yaitu hamemayu hayuning bawana, golong gilig, sawiji, greget, sengguh ora mingkuh.

\section{Landasan Sosial Kultural}

Pertama, Kabupaten Bantul secara demografi mayoritas merupakan wilayah agraris, dengan penduduk kebanyakan adalah petani, Kondisi ini tentunya berpengaruh terhadap kehidupan masyarakat Bantul yang masih memiliki budaya interaksi yang masih kental dengan budaya-budaya Jawa pada kehidupan sehari-hari sehingga kepedulian atas kelestarian budaya masih tinggi.

Kedua, Kekayaan budaya yang ada di Bantul dan tingginya kepedulian terhadap budaya maka kelestarian dan kreatifitas budaya akan tumbuh dan berkembang. Dan ketiga, pluralitas budaya yang ada di Bantul merupakan modal dasar dalam pengembangan pendidikan berbasis budaya, interaksi budaya yang diterjadi di tengah-tengah pluralitas budaya secara positif akan menghasilkan persilangan budaya atau akulturasi budaya, sebagaimana yang diutarakan oleh Toynbee dalam Hamengkubuwono X (2011, p. 12) bahwa kebudayaan akan berkembang apabila ada keseimbangan antara challenge dan response. Jika tantangan terlalu besar, sedangkan kemampuan untuk merespons terlalu kecil kebudayaan itu akan terdesak. Namun jika yang terjadi sebaliknya justru akan menumbuhkan kreatifitas masyarakat.

\section{Landasan Yuridis}

Landasan yuridis merupakan landasan yang dijadikan dasar hukum dilaksanakannya pendidikan berbasis budaya. Dalam hal ini yang menjadi landasan yuridis pendidikan berbasis budaya adalah Undang-Undang Sistem Pendidikan Nasional Nomor 20 tahun 2003, Peraturan Daerah Istimewa Yogyakarta Nomor 5 Tahun 2011 tentang Pedoman Pelaksanaan Pendidikan Berbasis Budaya, Peraturan Bupati Kabupaten Bantul tentang pelaksanaan pendidikan kearifan lokal dan surat keputusan PPD (Pengembangan Pendidikan Dasar).

Berdasarkan uraian tersebut, maka konsep pendidikan berbasis budaya dapat dipahami sebagai upaya untuk menggali, menjaga, dan mengembangkan budaya lokal dalam rangka mewujudkan generasi yang sadar budaya. Pendidikan berbasis budaya diselenggarakan dengan menempatkan budaya sebagai salah satu sumber sekaligus orientasi dari pendidikan itu sendiri. Tentu hal ini sesuai dengan cita-cita pendidikan nasional. Pendidikan nasional dalam arti yang lebih luas bertujuan untuk mengembangkan potensi diri peserta didik untuk memiliki kekuatan spiritual keagamaan, pengendalian diri, kepribadian, kecerdasan, akhlak mulia, serta keterampilan yang diperlukan dirinya, masyarakat, bangsa dan negara.

Konsep pendidikan berbasis budaya menurut Dinas Pendidikan Dasar Kabupaten Bantul adalah pendidikan yang di dalamnya mencakup aspek-aspek sebagai berikut: Pertama, Content atau isi materi pembelajaran memiliki relevansi dari unsurunsur budaya lokal masing-masing. Kedua, Proses pembelajaran senantiasa dikaitkan dan menggali serta menjunjung tinggi nilai-nilai luhur budaya. Ketiga, Menjadikan kearifan lokal sebagai raw input, media sekaligus sebagai orientasi pendidikan

Kearifan lokal sebagai kekayaan yang nilainya sangatlah berharga seharusnya mampu dilihat sebagai potensi yang dapat di eksplorasi oleh pendidikan. Keberadaan kearifan lokal dalam pendidikan tentunya akan memberikan rasa sekaligus warna 
yang berbeda dalam proses dan orientasi pendidikan. Kearifan lokal yang merupakan hasil cipta, karya dan karsa masyarakat selain mengandung nilai-nilai luhur, kearifan lokal juga merupakan identitas kultural yang seharusnya di transformasikan dari generasi ke generasi. Sebagaimana yang disebutkan oleh Kroeber \& Kluckhlon (Jenks, 2013, p. 50) bahwa kebudayaan terdiri atas pola-pola, baik yang eksplisit maupun yang implisit, tentang dan untuk perilaku, yang diperoleh dan disebarluaskan melalui simbol-simbol, membentuk prestasi khas kelompok-kelompok manusia, termasuk perwujudannya dalam bentuk berbagai artefak.

Pendidikan sebagaimana dijelaskan sebelumnya merupakan instrumen yang paling efektif dalam transformasi sosial budaya. Pendidikan yang memiliki relevansi dengan kondisi sosial masyarakatnya mampu melahirkan individu yang mampu melibatkan diri secara radikal di dalam kehidupan sosial masyarakat. Menjadikan kearifan lokal sebagai raw input pendidikan tentu akan menjadikan pendidikan berbasis budaya akan lebih mudah terealisasi, mengingat bahwa Bantul dengan ciri dan karakter ekologi dan demografinya sangat mendukung akan hal itu, kondisi ekologi dan demografi Kabupaten Bantul secara alamiah telah membentuk lingkungan yang syarat akan nilai-nilai budaya.

Dalam konteks kebudayaan lokal Daerah Istimewa Yogyakarta, khususnya Kabupaten Bantul. frasa-frasa kearifan lokal yang senantiasa ditransformasikan dari generasi ke generasi yang lain adalah Hamemayu Hayuning Bawana. Frasa yang diyakini dan dipegang teguh oleh masyarakat Jawa khususnya Daerah Istimewa Yogyakarta ini telah menjadi filsafat hidup dari generasi ke generasi, karena keluhuran serta tetap memiliki relevansi dengan kondisi kekinian dan kedisinian.

Dalam Hamengkubuwono X (2011, p. 8) dijelaskan bahwa Hamemayu Hayuning Bawana secara bahasa memiliki arti "hayu" berasal dari "rahayu", yang berarti sejahtera/selamat. Maknanya tidak terlepas dari prinsip keselarasan masyarakat Jawa. Seca- ra universal diartikan sebagai nilai-nilai yang menjamin keselamatan alam semesta yang berkelanjutan, bertumpu pada keputusan generasi sekarang untuk kemanfaatan generasi selanjutnya. Hubungan harmonis antara manusia dengan alam yang pada akhirnya akan membentuk Jalma Indonesia kang utama (manusia Indonesia yang utama), manusia paripurna, seorang pemimpin-negarawan yang menggambarkan sejati-jatining satriya (satria sejati) yang sudah sampai pada tataran "kesempurnaan" ideal yang membawa misi Hamemayu Hayuning Bawana (memuliakan/kesejahteraan dan keselamatan dunia). Gambaran ideal ini selaras dengan pandangan Kuntowijoyo (2006, p. 92) yang menjelaskan bahwa manusia hadir ke dunia dengan membawa misi prophetik yaitu misi kenabian atau keselamatan bagi kehidupan dunia.

Selain itu, falsafah Jawa yang lain adalah golong gilig itu bersatu padu kemudian sawiji adalah menyatu, kemudian golong gilig kemudian nyawiji, greget adalah semangat, nyawiji sudah menyatu kemudian timbul semangat, Sengguh ora mingkuh, sengguh adalah menjaga harkat dan martabat, kuat memegang prinsip yang tidak mudah tergoyahkan. Dalam praktek pendidikan, masyarakat Jawa juga memiliki kearifan lokal yang masih dipegang sampai saat ini yaitu ing ngarso sung tulodho, ketika didepan memberi contoh, ing madya mangun karsa ketika ditengah membangun kehendak, tut wuri handayani, ketika di belakang memberi dorongan. Dan mengedepankan sifat asah yaitu selalu menambah pengetahuan, cakrawala. Asih adalah memberikan ilmu, saling memberi. Asuh adalah mendidik, serta menggunakan metode niteni, diawali dengan niteni, anak pada dasarnya adalah niteni yang pertama kemudian niroke, nambahi itu mengembangkan, nularke adalah menularkan dengan orang lain kemudian nebarke adalah menyebarluaskan.

Pendidikan tidak hanya menjadi proses transmisi pengetahuan namun juga akan menjadi sebuah proses pembentukan manusia yang yang utama dan unggul (jalma utama) serta memiliki budi pekerti yang luhur yang pada akhirnya mampu 
mengemban misi kebaikan dan keharmonisan serta keseimbangan antara manusia dan alam (Hamemayu Hayuning Bawana).

Berdasarkan uraian tersebut, maka dapat disimpulkan bahwa konsep pendidikan berbasis budaya di Kabupaten Bantul adalah pendidikan yang dirancang berdasarkan nilai-nilai budaya, baik materi, proses dan orientasi pendidikan dengan melibatkan stake holders (pemerintah, tokoh budaya, sekolah, pendidik dan orang tua siswa) dalam perumusan, proses dan evaluasi pendidikanya yang bertujuan untuk melahirkan generasi-generasi yang mengenal, memahami dan menghayati serta mengamalkan praktek dan nilai-nilai budaya lokal dalam rangka menjaga kelestarian budaya dan keharmonisan kehidupan.

Strategi Implementasi Pendidikan Berbasis Budaya Dinas Pendidikan Dasar Kabupaten Bantul

Strategi implementasi merupakan cara dan upaya untuk melaksanakan sesuatu yang telah direncanakan dalam rangka mencapai tujuan dari apa yang telah ditetapkan dengan mengoptimalkan segala sumber daya yang ada. Maka berdasarkan temuan penulis, strategi implementasi pendidikan berbasis budaya Dinas Pendidikan Dasar Kabupaten Bantul adalah sebagai berikut:

Menyusun Rencana Implementasi Pendidikan Berbasis Budaya

Menyusun Rencana Implementasi Pendidikan Berbasis Budaya Dalam proses mempersiapkan sebuah keputusan untuk implementasi pendidikan berbasis budaya juga mengikuti setiap tahap-tahapan perencanaan pendidikan yang dilakukan Dinas Pendidikan Dasar Kabupaten Bantul dalam jangka waktu tertentu. Adapun proses dan tahapan penyusunan perencanaan di Dinas Pendidikan Dasar Kabupaten Bantul adalah sebagai berikut:

Pertama, melakukan analisis kebutuhan dengan menampung aspirasi dari masyarakat yang akan dijadikan sebagai bagian yang akan dianalisis. Kedua, mengidentifikasi isu-isu strategis pendidikan dasar di Bantul dan hasil evaluasi kegiatan se- belumnya. Ketiga, mengumpulkan masukan dari UPT (Unit Pelaksana Teknis) dan kelompok kerja SD Keempat, Rapat Kerja Daerah dilaksanakan setelah pelaksanaan Musrenbang (Musyawarah Rencana Pembangunan). Kelima, selanjutnya dibahas oleh DPRD Komisi D yang membidangi pendidikan. Kemudian di plenokan oleh DPRD dan disetujui menjadi anggaran.

Melibatkan Stakeholders Dalam Proses Penyusunan Rencana Implementasi Pendidikan Berbasis Budaya

Strategi yang kedua untuk dapat mengimplementasikan pendidikan berbasis budaya Dinas Pendidikan Dasar Kabupaten Bantul adalah melibatkan beberapa stakeholders dalam proses penyusunan rencana. Melibatkan berbagai pihak dalam penyusunan rencana program, tentu tidak hanya untuk mendapatkan aspirasi, ide atau gagasan yang berasal dari kebutuhan masyarakat, namun juga akan menimbulkan rasa tanggung jawab dan komitmen bersama dalam merealisasikan apa yang telah di rencanakan. Rasa tanggung jawab dan komitmen dari semua pihak merupakan kunci dari keberhasilan suatu program yang akan dilaksanakan.

\section{Menetapkan Rencana Strategis dan Operasional}

Rencana strategis pendidikan berbasis budaya Dinas Pendidikan Dasar Kabupaten Bantul adalah menciptakan warga Bantul memiliki kecerdasan spiritual, emosional, sosial intelektual dan juga kinestetik, berakhlak mulia, berbudi pekerti luhur dan berkepribadian Indonesia. Berdasarkan penjelasan diatas dapat di pahami bahwa rencana jangka panjang Dinas Pendidikan Dasar Kabupaten Bantul untuk pendidikan berbasis budaya adalah :

Pertama, menciptakan masyarakat Bantul yang cerdas secara komprehensif, baik kecerdasan spiritual, emosional, sosial intelektual dan juga kinestetik, cepat dan tepat proses berpikirnya, mudah menyesuaikan diri, sehingga terbentuk manusia yang unggul.

Kedua, dinas Pendidikan Dasar Kabupaten Bantul juga ingin menciptakan masyarakat Bantul memiliki akhlak yaitu me- 
miliki budi pekerti luhur yang dapat ditunjukan dengan sikap dan perilaku dalam kehidupan sehari-hari yang sesuai dengan agama yang diyakini. Ketiga, Dinas Pendidikan Dasar Kabupaten Bantul juga ingin menciptakan masyarakat Bantul memiliki kepribadian Indonesia artinya memiliki karakter dan budaya Indonesia dengan Hamemayu hayuning bawono dan bangga terhadap tanah air dan bangsanya sendiri, sehingga mampu membangun bangsa dan negara sejajar dengan bangsa-bangsa lain di dunia dengan tidak meninggalkan jati diri bangsa serta kearifan lokal.

Dinas Pendidikan Dasar Kabupaten Bantul juga telah melakukan kegiatankegiatan yang mendukung implementasi pendidikan berbasis budaya. Dimulai tahun 2008 yait Refleksi, Seminar, Workshop, Pengadaan Audio Visual, Pembuatan Modul, Pembuatan Model Pembelajaran dengan Audio Visual. Tahun 2009 yaitu In Servis Training, On Servis Training, Sosialisasi Pembelajaran Berbasis TIK, Pelatihan Pengawas, Monitoring. Tahun 2010 yaitu Diklat Pembuatan Pembuatan Batik, Workshop Pembuatan LKS, Diklat Pembuatan RKAS, Pelatihan Pengawas. Tahun 2011 yaitu Lomba Karawitan, Produksi Sumber Belajar dengan Audio Visual, Lomba Mengajar, Festifal Kearifan Lokal. Tahun 2012 yaitu Lomba Karawitan, Lomba Mengajar, Bintek Pembelajaran Berbasis Kearifan Lokal dan Hak-Hak Anak, Cetak Buku Kurikulum, Pembuatan Buku Pegangan Siswa. Tahun 2013 yaitu Pencetakan Modul Pembelajaran Berbasis Kearifan Lokal dan Hak-hak Anak, Pencetakan Buku Bahan Ajar Pendidikan Batik, Lomba Penelitian Tindakan Kelas/Sekolah Pelaksanaan P2D Berbasis Kearifal lokal, Festifal Kearifan Lokal anak SD, Lomba Karawitan Siswa dan Guru, Lomba Sendratari. Tahun 2014 yaitu Lomba Karawitan Siswa dan Guru, Lomba PTS Pelaksanaan P2D Berbasis Kearifal lokal, Pembuatan Buku Sekar Macapat Wewarah Budi Pekerti, Lomba Sesorah Pelaksanaan P2D Berbasis Kearifal lokal dan Hak-hak Anak, Bimtek Implementasi Kearifan Lokal dan Hak-hak Anak pada Kurikulum 2013.
Menyusun Strategi Implementasi Pendidikan Berbasis Budaya Untuk Tingkat Satuan Pendidikan Di Kabupaten Bantul

Secara teknis, implementasi pendidikan berbasis budaya untuk tingkat satuan pendidikan di Kabupaten Bantul dilakukan melalui empat strategi secara terpadu yaitu: Pertama, terintegrasi pada semua mata pelajaran atau tema dengan nilainilai luhur budaya. Kedua, Melalui muatan lokal dalam kurikulum. Ketiga, melalui ekstra kurikuler. Keempat, Melalui kegiatankegiatan yang bersifat insidental.

\section{Melakukan Sosialisasi Pendidikan Berbasis Budaya}

Dinas Pendidikan pada tingkat kota atau kabupaten memiliki tugas dan tanggungjawab untuk melakukan sosialisasi atas semua kebijakan yang telah dikeluarkan. Dinas Pendidikan Dasar Kabupaten Bantul mengeluarkan kebijakan tentang pendidikan berbasis budaya, maka untuk dapat dilaksanakan keseluruh sekolah khususnya untuk Sekolah dasar yang ada di Kabupaten Bantul maka Dinas melakukan sosialisasi tentang konsep dan strategi implementasi pendidikan berbasis budaya kepada tingkat satuan pendidikan. Oleh karena itu, Dinas Pendidikan Dasar Kabupaten Bantul melakukan berbagai macam kegiatan diantaranya Diklat, seminar, workshop. Melalui kegiatan tersebut sekaligus sebagai upaya untuk mensosialisasikan konsep dan implementasi pendidikan berbasis budaya.

Meningkatkan Kapasitas Sumber Daya Manusia

Sumber daya manusia merupakan unsur utama dalam implementasi pendidikan berbasis budaya, sumber daya manusia yang dimaksud adalah Pemerintah sendiri, Kepala Sekolah, pendidik, pengawas dan stakeholders lainnya. Upaya yang dilakukan oleh Dinas Pendidikan Dasar Kabupaten Bantul untuk mengimplementasikan pendidikan berbasis budaya adalah mempersiapkan sumber daya manusia yang ada melalui beberapa cara yaitu: seminar, workshop, diklat, penelitian tindakan kelas, dan penyegaran. 
Mempersiapkan Sarana Prasarana untuk Menunjang Implementasi Pendidikan Berbasis Budaya

Sarana dan prasarana merupakan penunjang yang sangat penting dalam implementasi pendidikan berbasis budaya. Sarana itu sendiri adalah sesuatu yang dapat digunakan atau alat yang dapat dipergunakan untuk mencapai tujuan sedangkan prasarana adalah alat yang menjadi penunjang terlaksananya kegiatan. Untuk mempersiapkan sarana dan prasarana penunjang pendidikan berbasis budaya Dinas Pendidikan Dasar Kabupaten Bantul memberikan bantuan berupa dana untuk setiap sekolah dasar yang ada di Kabupaten Bantul. Dana tersebut dipergunakan untuk melengkapi sarana dan prasarana dalam upaya pengeimplementasian pendidikan berbasis budaya. Sehingga, dana tersebut digunakan untuk membeli perlengkapan yang dibutuhkan seperti membeli mainan anak tradisional, untuk membeli wayang, dan untuk beli semua keperluan sebagai penunjang keterlaksanaan pendidikan berbasis budaya di sekolah. Selain memberikan bantuan berupa dana Dinas Pendidikan Dasar Kabupaten Bantul juga memberikan dana ada yang berupa benda yaitu gamelan untuk masing-masing sekolah setiap tahun kurang lebih 4 sekolah setiap tahunya.

Berdasarkan hasil pembahasan tersebut, maka dapat diambil kesimpulan bahwa strategi yang dilakukan oleh Dinas Pendidikan Dasar Kabupaten Bantul dalam mengimplementasikan pendidikan berbasis budaya adalah pertama; merumuskan rencana program pendidikan berbasis budaya, kedua; melibatkan stakeholders dalam proses penyusunan rencana implementasi pendidikan berbasis budaya Dinas Pendidikan Dasar Kabupaten Bantul, ketiga; menetapkan rencana strategis dan operasional, keempat; menyusun strategi implementasi pendidikan berbasis budaya untuk Tingkat Satuan Pendidikan Di Kabupaten Bantul, kelima; melakukan sosialisasi pendidikan berbasis budaya, keenam; meningkatkan kapasitas sumber daya manusia, ketujuh; mempersiapkan sarana prasarana untuk menunjang implementasi Pendidikan Ber- basis Budaya di Sekolah Dasar Kabupaten Bantul.

Strategi Implementasi Pendidikan Berbasis Budaya Di Tingkat Satuan Pendidikan

Strategi implementasi pendidikan berbasis budaya yang diterapkan oleh sekolah adalah sebagai berikut: Pertama, mengintegrasikan nilai budaya dalam proses pembelajaran. Berdasarkan hasil penelitian di tiga sekolah dasar yang ada di Kabupaten Bantul, yaitu SD 1 Trirenggo, SD Sendangsari Pajangan dan SD 1 Petir Piyungan menunjukkan bahwa nilai-nilai budaya terintegrasi dalam proses pembelajaran. Hal ini ditunjukkan dalam rencana praktik pembelajaran (RPP) yang disusun oleh guru. Adapun praksis pembelajaran yang mengintegrasikan nilai-nilai budaya dilakukan dengan mengaitkan mata pelajaran yang disampaikan dengan nilai-nilai budaya, selain itu juga dengan menjadikan alat-alat tradisional sebagai media pembelajaran.

Kedua, Menjadikan produk kebudayaan sebagai muatan lokal dalam kurikulum sekolah. Kurikulum yang dimaksud adalah serangkaian rumusan yang disusun berdasarkan kebutuhan sekolah, daerah serta dikuatkan melalui keputusan Dinas Pendidikan Pemuda Dan Olahraga Daerah Istimewa Yogyakarta. Muatan lokal wajib di Daerah Istimewa Yogyakarta adalah Bahasa Jawa, sedangkan muatan lokal wajib di Kabupaten Bantul adalah bahasa Jawa dan membatik. Muatan lokal yang sifatnya pilihan disesuaikan dengan potensi setiap sekolah dan keunggulan daerahnya.

Implementasi pendidikan berbasis budaya dengan menjadikan produk kebudayaan sebagai muatan lokal dalam kurikulum sekolah sebagaimana yang telah dijelaskan sebelumnya merupakan bentuk dari kurikulum mandiri (single subject matter) yaitu bentuk kurikulum yang menjadikan kearifan lokal atau produk budaya dilakasanakan dalam bentuk mata pelajaran.

Muatan lokal wajib di Kabupaten Bantul adalah Bahasa Jawa dan Membatik sedangkan muatan lokal pilihan di Kabupaten Bantul yaitu ada gamelan, memasak tradisional, membuat kriya/pahat/kerajin- 
an/anyam-anyaman/keramik, permainan tradisional, pakaian tradisional, makanan tradisional, seni tari, seni karawitan, seni pertunjukan, seni teater, seni sastra Jawa, upacara pernikahan, upacara khitanan, pergaulan hidup bertetangga dan seni musik.

Ketiga, menjadikan kearifan lokal sebagai kegiatan ekstra kurikuler sekolah. Berdasarkan hasil penelitian di tiga sekolah dasar yang ada di Kabupaten Bantul, yaitu SD 1 Trirenggo Bantul dalam kegiatan ekstra kurikulernya adalah seni tari, karawitan dan pramuladi, sedangkan SD Sendangsari Pajangan Bantul kegiatan ekstra kurikuler yang dilaksanakan adalah seni tari, karawitan dan olah pangan tradisional, begitu pula dengan SD 1 Petir Piyungan, kegiatan ekstra kurikuler yang diselenggarakan adalah seni tari dan karawitan. Berdasarkan uraian tersebut, maka dapat diambil kesimpulan bahwa seni tari dan karawitan merupakan kegiatan ekstra kurikuler yang disetiap sekolah dilaksanakan, sedangkan yang membedakan adalah adanya kegiatan ekstra kurikuler yang diselenggarakan berdasarkan keunggulan dari daerah masingmasing sekolah. Seperti SD Sendangsari Pajangan dengan olah pangan tradisional dan SD 1 Trirenggo dengan pramuladi serta SD 1 Petir Piyungan dengan karawitan sebagai keunggulannya.

Keempat, Melaksanakan kegiatan-kegiatan yang berkaitan dengan budaya. Berdasarkan hasil penelitian ditiga sekolah dasar yang ada di Kabupaten Bantul, yaitu SD 1 Trirenggo, SD Sendangsari Pajangan dan SD 1 Petir Piyungan menunjukkan bahwa pelaksanaan kegiataan yang berkaitan dengan budaya bersifat rutin dan insidental. Kegiatan rutin sekolah yang berkaitan dengan budaya adalah melaksanakan festival, pertunjukan dan perayaan-perayaan hari besar nasional dengan menampilkan keterampilan dan kemampuan dalam aspek ekspresi budaya. sebagai contoh SD Sendangsari Pajangan yang secara rutin melaksanakan gebyar kearifan lokal, sedangkan SD 1 Trirenggo Bantul melaksanakan gebyar seni dan SD 1 Petir Piyungan diselenggarakan pementasan karawitan disetiap ulang tahun sekolah. Selain kegiatan yang bersifat rutin, kegiatan-kegiatan yang diselenggarakan secara insidental adalah mengikuti kegiatan-kegiatan yang diselenggarakan oleh Pemerintah Kabupaten Bantul, baik itu dari Dinas Pendidikan Dasar maupun dari instansi pemerintah yang lain.

\section{Simpulan}

Berdasarkan hasil penelitian ini dapat disimpulkan sebagai berikut. Pendidikan berbasis budaya adalah seluruh pengelolaan dan penyelenggaraan pendidikan dilaksanakan berdasarkan sistem pendidikan nasional dengan menjunjung tinggi nilai-nilai luhur budaya dan menjadikan konten materi dan proses tidak lepas dari aspek budaya yang ada di setiap wilayah Kabupaten Bantul serta menjadikan kearifan lokal Kabupaten Bantul sebagai raw input, media, sekaligus sebagai orientasi pendidikan dalam rangka menggali nilainilai luhur budaya yang telah hidup dan tumbuh secara turun temurun untuk diaktualisasikan kembali dalam pendidikan. Pendidikan berbasis budaya dalam aspek praksis pembelajarannya menggunakan konsep ing ngarso sung tulodho, ing madya mangun karsa, tut wuri handayani mengedepankan sifat asah, asih, dan asuh. Metode yang digunakan adalah niteni, niroake, nambahi, nularke, dan nebarke.

Strategi implementasi pendidikan berbasis budaya Dinas Pendidikan Dasar Kabupaten Bantul adalah pertama; merumuskan rencana program pendidikan berbasis budaya, kedua; melibatkan stakeholders dalam proses penyusunan rencana implementasi pendidikan berbasis budaya Dinas Pendidikan Dasar Kabupaten Bantul, ketiga; menetapkan rencana strategis dan operasional, keempat; menyusun strategi implementasi pendidikan berbasis budaya untuk tingkat satuan pendidikan Di Kabupaten Bantul, kelima; melakukan sosialisasi pendidikan berbasis budaya, keenam; meningkatkan kapasitas sumber daya manusia, ketujuh; mempersiapkan sarana prasarana untuk menunjang implementasi pendidikan berbasis budaya di Sekolah Dasar Kabupaten Bantul. 
Implementasi pendidikan berbasis budaya pada tingkat satuan pendidikan di Kabupaten Bantul adalah memasukkan budaya dan kearifan lokal ke dalam kurikulum sekolah dalam bentuk kurikulum terpadu atau terintegrasi dan kurikulum mandiri (single subject matter). Selain itu juga sekolah menjadikan budaya dan kearifan lokal sebagai kegiatan ekstra kurikuler sekolah dan melaksanakan kegiatan secara rutin maupun insidental dalam rangka memberikan ruang untuk menampilkan keterampilan dan kemampuan peserta didik budaya dan kearifan lokal.

Berdasarkan simpulan tersebut, maka ada beberapa saran yang dapat diajukan yaitu: (1) Pemerintah Kabupaten Bantul khususnya Dinas Pendidikan Dasar harus memberikan perhatian, dukungan, fasilitas dan pendampingan yang lebih intensif kepada satuan pendidikan dalam melaksanakan pendidikan berbasis budaya, selain itu juga Dinas Pendidikan Dasar Kabupaten Bantul harus melaksanakan program-program dalam rangka peningkatan kualitas tenaga pendidik dan kependidikan; (2) Kepala Sekolah harus melakukan supervisi bagi para tenaga pendidik dalam melaksanakan pendidikan berbasis budaya khsusnya dalam proses pembelajaran. Sedangkan tenaga pendidik harus meningkatkan kualitas diri dalam aspek pemahaman dan praksis pendidikan berbasis budaya.

\section{Daftar Pustaka}

Basri, H. (2013). Landasan pendidikan. Bandung: CV Pustaka Setia.

Hamengkubuwono, X. (Desember 2011). Menggugah hati, mengetuk nurani, membangun peradaban berbasis nilainilai kemanusiaan. Pidato menganugrahan gelar doctor honoris causa bidang kemanusiaan dari UGM, di Universitas Gadjah Mada Yogyakarta.

Friedman, J. (1994). Cultural identity $\mathcal{E}$ global process. London: SAGE.

Gubernur Daerah Istimewa Yogyakarta. (2011). Peraturan gubernur daerah istimewa yogyakarta nomor 05 tahun 2011 tentang pengelolaan dan penyelenggaraan pendidikan berbasis budaya.

Jenks, C. (2013). Culture studi kebudayaan (Terjemahan Erika Setyawati). New York: Routledge Taylor \& Francis Group. (Buku asli diterbitkan tahun 1993).

Kottak, C. P., (1974). Cultural antropology. USA: McGraw-Hill,Inc.

Kuntowijoyo. (2006). Islam sebagai ilmu epistimologi, metodologi dan etika. Yogyakarta: Tiara Wacana.

Meliono, I. (2011). Understanding the nusantara thought and local wisdom as an aspect of the indonesian education tawarikh. International journal for historical studies, Vol. 2. No. 2. Diambil pada tanggal 12 Agustus 2015, dari http://www.historicalJournal.com Ljournal.index.php.

Miles, M. B., \& Huberman, A. M. (1994). Qualitative data analysis. (2nded.). London: Sage Publication.

Nieto, S. (2010). Language, culture, and teaching critical perspectives. (2nded.). New York: Routledge Taylor \& Francis Group.

Taylor, E. B. (1871). Primitive culture: Researches into the development of mythology, philosophy, religion, art, and contum. London: John Murray, Albemarle street.

Thut, I. N., \& Adams, D. ( 2005). Pola - pola pendidikan dalam masyarakat kontemporer seri pendidikan perbandingan. (Terjemahan SPA Team Work). New York: McGrawHill Book Comapany. (Buku asli diterbitkan tahun 1984).

Tirtharahardja, U., \& La Sulo, S.L. (2005). Pengantar pendidikan. Jakarta. PT Rineka Cipta.

Wahab, S. A. (2015). Analisis kebijakan dari formulasi kepenyusunan model-model implementasi kebijakan publik. Jakarta: Bumi Aksara.

Pai, Young (1990). Cultural foundations of education. USA: Merri Publishing Company. 